\title{
Communication of the TeleCTG innovation diffusion process with midwives' participation and empowerment
}

\author{
Retor Aquinaldo Wirabuanaputera Kaligis ${ }^{1}$, Faridhian Anshari ${ }^{2}$, Sofia Primalisanti Devi ${ }^{3}$ \\ 1,2,3 Universitas Pancasila, Jakarta, Indonesia
}

\begin{abstract}
TeleCTG is a telemedicine-based medium technology that Indonesia makes. Nowadays, Cardiotocography has only been operated by an obstetrician/gynecologist (ob-gyn) at the hospital. The occurrence of TeleCTG at Puskesmas (the public health center) helps midwives send the diagnosis online to an ob-gyn for immediate response. This technology helps to equalize the quality of health services. The research purpose is to analyze the innovation diffusion process in using TeleCTG medical devices for participation and empowerment of midwives as the frontline of public health services in the Kupang. Diffusion of innovation is a persuasive process of spreading innovation through specific channels among the members of a social system. Using an exploratory sequential mixed-methods design, then this research explored qualitative data through in-depth interviews with four informants. Questionnaires were distributed to draw the generalizability of the findings at the population level. The population is midwives from 13 sub-districts using TeleCTG in Kupang and cluster sampling techniques. Path analysis is used to see the causal relationship among elements of innovation diffusion, midwives' participation, and midwives' empowerment. The results found that the diffusion of innovation encourages the participation of midwives, then the participation level increases empowerment. The diffusion of innovation does not directly influence the empowerment of midwives, but there is an indirect effect of the elements on the empowerment mediated by midwives' participation. As the final discussion, the participation of midwives is the key to increasing the empowerment of Puskesmas midwives in Kupang.
\end{abstract}

Keywords: Elements of innovation diffusion; TeleCTG; participation level; empowerment; midwives

\section{Komunikasi proses difusi inovasi TeleCTG dengan partisipasi dan pemberdayaan bidan}

\section{ABSTRAK}

TeleCTG merupakan alat medis karya anak bangsa Indonesia dengan teknologi medium berbasis telemedicine. Selama ini, CTG (Cardiotocography) hanya ditemukan di rumah sakit yang dioperasikan dokter ob-gyn. Kehadiran TeleCTG di Puskesmas membantu para bidan setempat mengirim hasil diagnosis secara online kepada para dokter obgyn sehingga tindakan medis bisa segera dilakukan. Teknologi tersebut membantu pemerataan kualitas pelayanan kesehatan karena mayoritas Puskesmas di Indonesia tidak memiliki dokter jaga. Tujuan penelitian ini mempelajari proses difusi inovasi pemanfaatan alat medis TeleCTG dalam kaitannya dengan aspek partisipasi dan pemberdayaan bidan Puskesmas sebagai garda terdepan pelayanan kesehatan masyarakat di Kabupaten Kupang. Difusi inovasi merupakan proses persuasi penyebaran inovasi melalui saluransaluran tertentu di antara para anggota suatu sistem sosial. Dengan menggunakan metode campuran jenis sekuensial eksploratori, penelitian ini terlebih dulu mengeksplorasi data kualitatif melalui wawancara mendalam empat informan kunci. Penyebaran kuesioner dilakukan untuk menarik generalisasi temuan pada tingkat populasi. Populasinya adalah para bidan dari 13 kecamatan pengguna TeleCTG di Kabupaten Kupang, adapun teknik penarikan sampling menggunakan cluster sampling. Analisa Jalur digunakan untuk melihat hubungan kausal antara elemen difusi inovasi, partisipasi bidan, dan pemberdayaan bidan. Hasil penelitian ini menemukan difusi inovasi perlu dikaitkan dengan partisipasi bidan agar prosesnya tidak berlangsung linear dan top down. Pemberdayaan bidan diperlukan agar proses difusi inovasi bisa berjalan secara berkelanjutan. Dengan demikian partisipasi dan pemberdayaan bidan menjadi bagian tak terpisahkan dalam proses difusi inovasi TeleCTG.

Kata-Kata kunci: Elemen difusi inovasi; TeleCTG; tingkat partisipasi; pemberdayaan; bidan

Korespondensi: Dr. Retor Aquinaldo Wirabuanaputera Kaligis, M.Si., Universitas Pancasila, Jalan Srengseng Sawah, Jagakarsa, Jakarta Selatan-12640,62217870451,Email: retorawkaligis@univpancasila.ac.id 


\section{INTRODUCTION}

Puskesmas (the public health center) and the health sector in Indonesia face unequal distribution of health facilities and qualified medical personnel. Especially outside Java, difficult geographical conditions are not supported by adequate transportation infrastructure. People in remote areas are often late in getting health services because they have to pass through mountains and hills, cross rivers, or oceans to access better health facilities in urban areas.

This condition is experienced by pregnant women in remote areas who intend to check the health of themselves and their fetuses. With an average background of lower socioeconomic status, they only have access to local health facilities with minimal equipment and without the presence of a doctor. This issue contributes to the high maternal and infant mortality rate in Indonesia.

According to the results of Survey Penduduk Antar Sensus (SUPAS) 2015, the maternal mortality rate in Indonesia is still 305 per 100 thousand live births, still far from the Sustainable Development Goals (SDGs) to reduce the global maternal mortality rate to less than 70 per 100,000 by 2030 . The results of SUSENAS in March 2020 showed that as many as 88 out of 100 thousand gave birth to liveborn children in the last two years, and the last live-born children were born in health facilities. Women in urban areas have a higher percentage than women in rural areas, 94.03 percent compared to 80.39 percent. Low socioeconomic factors also affect maternal mortality due to access problems that prevent mothers from lowincome families from accessing higher-quality health facilities due to high costs (Badan Pusat Statistik RI, 2020).

Puskesmas is the spearhead of health services in the community to the lower levels, including handling pregnant women. In limited health facilities and the number of specialist doctors who have not reached remote areas of the country, TeleCTG technology is one way out. So far, CTG (Cardiotocography) has only been found in hospitals operated by obstetricians (obstetrics and gynecology specialists). TeleCTG is a medical device made by Indonesians with medium technology based on telemedicine. How it works, the midwife

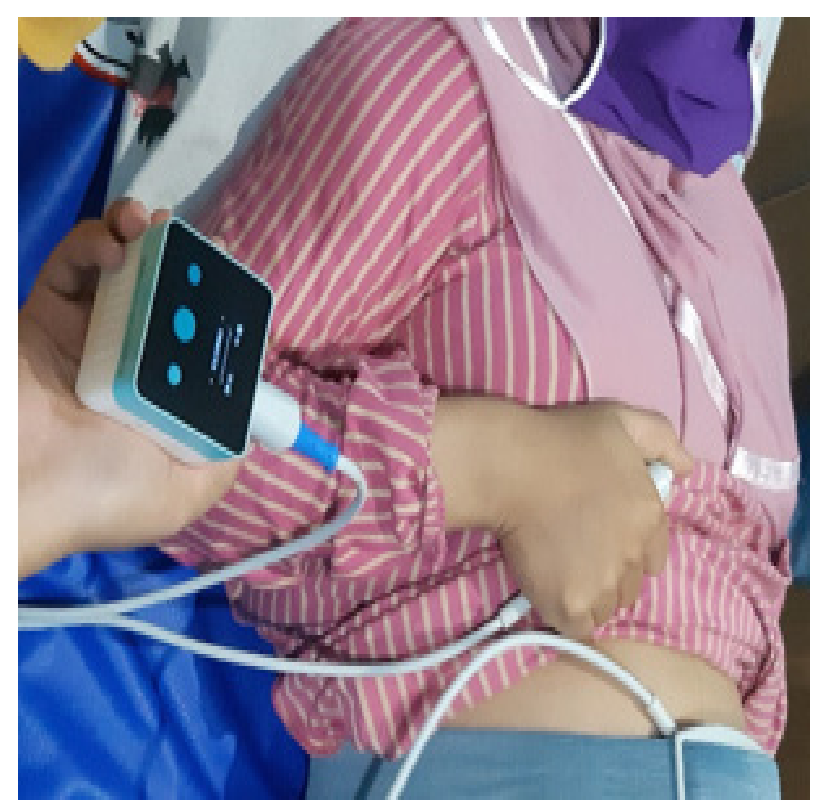

Source: Research documentation, 2020

Figure 1 Photo of the Pregnancy Diagnosis Process Using TeleCTG

installs TeleCTG on the patient's body for pregnant women and obtains the diagnosis results in the form of a graph on a smartphone to be sent online to ob-gyn doctors in different locations (Figure 1).

This technology, which was copyrighted by the Ministry of Law and Human Rights in 2017 and was clinically tested at the Faculty of Medicine, University of Indonesia, helps equalize the quality of health services. According to Law no. 4 of 2019 concerning Midwifery, midwives can make decisions and actions following their authority and scope of practice based on midwifery knowledge and tips. Beyond the midwifery authority and practice scope, midwives require coordination with doctors.

Access to delivery by midwives or doctors is essential to reduce maternal mortality and infant mortality (Sariyati et al., 2016). With TeleCTG, Puskesmas midwives in remote areas have the opportunity to collaborate with obgyn doctors in urban areas remotely. Midwives can take medical action quickly and precisely for patients with pregnant women at risk on the recommendation of an ob-gyn doctor online. TeleCTG also allows pregnant women at Puskesmas to enjoy CTG facilities so that they do not need to go to the hospital, which is time- 
consuming and costly. The TeleCTG provider stated that until Puskesmas midwives had used 2020 TeleCTG in Kupang (NTT) and Indramayu (West Java) districts, as well as independent midwives in Bekasi, West Java (Waluyo, 2020).

This research aims to study the diffusion process of innovation in the use of TeleCTG medical devices to detect the welfare of the fetus, mother, and baby concerning the participation and empowerment of midwives as the frontline health services in Kupang Regency. Kupang Regency was chosen because out of 24 subdistricts, there were 13 sub-districts already using TeleCTG medical devices. In all of these districts, the number of doctors is only 20 , while there are 241 midwives (Badan Pusat Statistik Kabupaten Kupang, 2021). In addition, amid the geographical condition of the islands and limited transportation infrastructure, this district only has one general hospital and no maternity hospital. Under these conditions, the midwife becomes highly relied upon by the community to assist with childbirth.

Diffusion of innovation is a persuasive process of spreading innovation through five attributes: relative advantage, compatibility, complexity, trialability, and observability (Rogers, 2003: 219: 259). First, the relative advantage is the advantage of innovation over others. The relative profit level can be divided into sub-dimensions of economic profitability, low initial costs, reduced inconvenience, social prestige, time and effort savings, and quick rewards. Second, compatibility and innovation are considered consistent with the prevailing values, past experiences, and the needs of potential adopters. Third, complexity, namely the degree of complexity-simplicity of an innovation being accessed, understood and used. Fourth, liability, namely the degree to which an innovation can be tested physiologically and according to the conditions of potential adopters. Fifth, observability means the ease of innovation is to be observed and communicated to others, while other innovations are difficult to observe or explain to others.

Diffusion involves an innovation communicated through certain channels over time among the members of a social system. Based on the classical formulation, in health, diffusion is a social process that occurs among people in response to learning about innovation, such as expanding or improving health. The diffusion principle can stimulate the spread of innovation, especially in low-resource settings, through dissemination strategies or diffusion designs (Dearing \& Cox, 2018).

The concept of diffusion of innovation shows that the spread of innovation takes place in one direction and is top-down. This is the most important critique of the popular concept in the 1960s to 1970s, along with the golden age of the modernization development paradigm. The present study analyzes the involvement of midwives in the diffusion process to overcome the bias in the spread of innovation that is oneway and top-down.

The participation ladder is used to see the level of participation in compliance, consultation, cooperation, co-learning, and collective action (Kanji \& Greenwood, 2001) First, compliance, where tasks with incentives are determined but the agenda and processes are directed by outsiders. Second, consultation, where local opinions are requested, outsiders analyze and decide the course of action. The third is cooperation, where local people work with outsiders to determine priorities; the responsibility for directing the process rests with outsiders. Fourth, co-learning, where local people and outsiders share knowledge, create new understandings and work together to form action plans. Fifth, collective action, which means local people set their agenda and mobilize to implement it without the presence of outsiders. The participation ladder is an analytical tool to assess a particular group's stage when the analysis is applied (Grace \& Grace, 2017).

Furthermore, the diffusion of innovation and participation of midwives is associated with the empowerment of midwives. The empowerment of midwives can be seen in terms of welfare, clinical competence, and complementary competencies. The welfare side is an increase in the welfare of midwives both directly and indirectly, clinical competence regarding medical midwifery services, while complimentary competencies include supporting midwifery practices that assist services (Tajmiati et al., 2016).

Based on a study, the diffusion of innovations can be applied to complex health care contexts, both for explanatory and intervention purposes. The diffusion of innovations offers a readymade set of concepts and approaches that can 
be used to explain the acceptance of health care policies and practices by individuals and organizations. The principle of diffusion is also operationalized to accelerate adoption rates and expand the reach of health innovations. (Dearing \& Cox, 2018)

The diffusion of innovations also requires providing information to potential adopters. Product information is communicated from the organization to the target market using promotional and advertising tools in the consumer market. This information is then further communicated through social exchanges and word of mouth. (Katona et al., 2011).

However, the TeleCTG innovation diffusion does not use promotional, and advertising tools but makes Komunitas Bidan Sehati organization the facilitator for using TeleCTG among midwives through organizational meetings, training, and the use of social media, especially WhatsApp groups (Shinta, 2020). Komunitas Bidan Sehati connects TeleCTG provider company, the Health-Office Kupang District, and local midwives, starting from trials, training, implementation to monitoring and evaluation. From this process, midwives as the target market carried out social exchanges, and the use of TeleCTG grew by word of mouth, so the participation of midwives became important. It is hoped that the involvement of midwives in the innovation diffusion process will enable the presence of TeleCTG to empower the midwives themselves.

The time lag between innovation in health care and its widespread use throughout the health system is also an issue. Factors that can help absorb innovation in different organizations are needed to enable innovation to change the health care system (Parston et al., 2015). This study tries to see the relevance of the participation and empowerment of midwives in the innovation diffusion process. The formulation of the research problem is how the process of innovation diffusion in the use of TeleCTG medical devices concerning participation and empowerment of Puskesmas midwives in Kupang Regency is?

The concept of diffusion of innovation that is one-way and top-down requires midwives' involvement and empowerment efforts. From previous studies, it can also be seen that there is a time lag between innovation in the health care sector and its use so that potential adopters need to be an essential part of the diffusion process to accelerate the use of an innovation. Academically, this research is expected to develop the diffusion of innovation theory by including subject participation as part of the diffusion process and aspects of empowerment as the goal. The practical benefits of this research are providing input to stakeholders to optimize the diffusion process of innovation in the use of health technology from industrial 4.0 products, which involves the participation of midwives to support their empowerment.

\section{RESEARCH METHODS}

This study uses an exploratory sequential mixed methods design by first exploring qualitative data and analyzing it; then, the results become the basis for compiling questionnaires, collecting, and analyzing quantitative data. In the final stage, interpretation is carried out. The collection of quantitative and qualitative data in one study sequentially brings together two types of information that provide broader understanding and insight that may not be obtained if done separately (Bowen et al., 2017: 10-27)explanatory, mixed methodology, which was undertaken on a sample of 533 academics (those employed by a university full time, part time, and hourly and who may be lecturers, tutors, instructors, researchers. In mixed research studies, the writing phase informs and is informed by other stages in the mixed research process (Leech, Onwuegbuzie, \& Combs, 2011). Mixed methods clarify various things, both at the level of generalization in the quantitative approach and depth in the qualitative approach (Huiberts, 2016: 4339). Thus, this study uses a mixed-methods approach to optimize the strengths and minimize the limitations of each approach.

In the first stage, qualitative data collection was conducted by interviewing key informants, namely Ari Waluyo, creator of TeleCTG/ CEO of PT Zetta Sehati Nusantara, which is a provider of TeleCTG (28 July 2020); Erna Shinta, Coordinator of Komunitas Bidan Sehati (25 August 2020); Tjokorda Swastika, Health Office Kupang District (11 November 2020); and Mariana Archoon Sailana, Puskesmas midwife in Kupang Regency (9 September 2020). Processing of interview data was 
carried out through the stages of open coding, axial coding, and selective coding (Creswell, 2017: 262). Furthermore, this study analyzed qualitative data to see the relationship among the elements of innovation diffusion with participation and midwives. Data validity checking used triangulation of sources from the four informants.

The collection of quantitative data followed the results of the qualitative data analysis to draw generalizations of the findings at the population level of midwives of Puskesmas in Kupang Regency. The distribution of the questionnaire via google form was carried out from 2 February to 1 April 2021. The population was midwives from 13 sub-districts using TeleCTG in Kupang Regency, consisting of 161 midwives. The sampling technique used was cluster sampling with a minimum of 2 midwives from the 13 sub-districts to obtain 55 midwives as respondents. Path Analysis is used to see the causal relationship between $X$ (innovation diffusion elements), $\mathrm{Z}$ (midwives participation), and Y (midwives empowerment). Data processing using SPSS Windows 22.0.

There are four hypotheses in quantitative research. The first hypothesis is that there is an effect of $\mathrm{X}$ (innovation diffusion elements) on Y (midwives' participation), with the criteria if the significance value is $<0.05$. Then the second hypothesis is that there is an effect of Z (midwives' participation) on $\mathrm{Y}$ (midwives' empowerment), with the criteria if the significance value is $<0.05$. Furthermore, the third hypothesis is that there is an effect of $\mathrm{X}$ (innovation diffusion elements) on $\mathrm{Y}$ (midwives empowerment), with the criteria if the significance value is $<0.05$. Finally, the fourth hypothesis is that there is an indirect effect of $X$ (innovation diffusion elements) on $\mathrm{Y}$ (midwives empowerment) mediated by $\mathrm{Z}$ (midwives participation), with the criterion if the $\mathrm{Z}$ count is $>1.96$.

The item validity test is used; namely, a key question item can be valid if strong support for the total score. Using Pearson correlation statistical calculation, decision making from item validity test if $r$ count $(+)$ and $r$ result $>$ $\mathrm{r}$ table then the statement item is valid. The number of respondents $(\mathrm{N})=55$, then $\mathrm{df}=(\mathrm{N}$ $2)=55-2=53$. With $\mathrm{df}=53$ and $\alpha=0.05$, the $\mathrm{r}$ table is 0.266 .

From the results of the calculation of the
$\mathrm{X}$ variable data (innovation diffusion elements), of the 20 items, there are two items (economic profitability and quick rewards) that are not valid, while the other 18 items are valid because the $r$ count values are above the $r$ table, which ranges from 0.312 to 0.734 . Then, in calculating the $\mathrm{Z}$ variable data (midwives participation), the 15 items used are valid, with the $r$ count values from 0.551 to 0.871 . Furthermore, the results of the calculation of the $\mathrm{Y}$ variable (midwives empowerment) 9 items used are all valid because the $r$ count values are above the $r$ table, which ranges from 0.452 to 0.696 .

Then the reliability test, based on the formulation of De Vellis, the research instrument is declared to be reasonably reliable if it has a Cronbach Alpha $>0.7$. The $\mathrm{X}$ reliability test (innovation diffusion elements) was conducted after eliminating two invalid items. From the results of the calculation of the reliability test, all variables have good reliability, namely: $\mathrm{X}$ (innovation diffusion elements): 0.882 , $\mathrm{Z}$ (midwives participation): 0.930 , and $\mathrm{Y}$ (midwives empowerment): 0.763 . That is, all variables can be reliable, or there is consistency.

\section{RESULTS AND DISCUSSION}

This research began by extracting qualitative data from in-depth interviews with four informants. The results of the interviews in the form of open coding were processed with axial coding. Furthermore, this research produces selective coding, which is made up of a matrix.

Five elements are analyzed based on the axial coding of innovation diffusion: relative advantage, compatibility, complexity, trialability, and observability. Elements of relative advantage revolve around economic gain, social prestige, or other advantages. Based on an interview with the TeleCTG provider, the TeleCTG examination is easy to do at Puskesmas so that it can reduce the maternal mortality rate (MMR) and the infant mortality rate (IMR) in the local community (Waluyo, 2020). The Kupang District Health Office recognized the decline in MMR that in 2018 the MMR in Kupang District was ten people, but after using TeleCTG, it became five people in 2019, the IMR also decreased (Swastika, 2020). The cost of a TeleCTG examination, which is cheaper than a CTG examination in a hospital, benefits the 
patient. Nevertheless, Puskesmas midwives in Kupang Regency cannot charge this fee because Puskesmas provides free medical treatment, and the TeleCTG examination fee has not yet been included in the BPJS component (Shinta, 2020). Thus, the midwives of Puskesmas in Kupang do not receive additional income from the use of TeleCTG

Even so, midwives at Puskesmas in Kupang Regency admitted to experiencing inner satisfaction. The reason is that pregnant women who experience medical risks are treated more quickly.

"In addition to saving time and energy, midwives are happy and comfortable with the presence of TeleCTG because it reduces the worry of high-risk handling patients. There is a special pride for midwives in examining pregnant women because they can use the latest medical technology which has received positive responses from patients.” (Sailana, 2020)

Second, the compatibility element concerns the acceptance of TeleCTG innovation, experience, and the needs of potential adopters, where this technology is helpful for pregnant women in the third trimester and has risk factors. Kupang Regency has a challenging geographical terrain (up and down mountains and crossing rivers), and infrastructure has not yet developed as in Java. In addition, until the end of 2020, no ob-gyn doctors were practicing in the entire district. With these conditions, technical constraints in operating TeleCTG and smartphone specifications are not a big problem for midwives at Puskesmas in Kupang Regency. This tool is practical because it is easy to carry and can be used in areas with only $1 \mathrm{G}$ or $2 \mathrm{G}$ networks, making it suitable for use in 3T (Disadvantaged, Frontier, and Outermost) areas that do not yet have a $3 \mathrm{G}$ or $4 \mathrm{G}$ network. With TeleCTG, midwives in remote areas can be guided online by ob-gyn doctors provided by TeleCTG providers in Jakarta to treat patients with at-risk pregnant women. According to the Puskesmas midwife, initially, the patients were afraid that TeleCTG would negatively impact radiation. However, after being explained using language that was easy to understand, the fear disappeared, especially during TeleCTG examination, the patient could hear the baby's heartbeat (Sailana, 2020).
Third, complexity, in the form of the difficulty level of TeleCTG innovation and its use. The results of interviews with the Health Office Kupang District, Coordinator of Komunitas Bidan Sehati, and Puskesmas midwife found that at the beginning of the use of TeleCTG, there were difficulties in changing the habits of medical personnel, most of whom were still using the manual method, switching to digital data entry using a smartphone connected to the application. In addition, there is a level of difficulty when installing the device because it must fit in the patient's body so as not to face obstacles. Because this TeleCTG tool is a new thing that must be disseminated using research, the TeleCTG provider provides face-to-face training and asks midwives for input. After going through a series of training, the worries of the midwives gradually disappeared, and the midwives were generally able to install the device well.

The process of reading the TeleCTG data is a problem because previously, it could only be done by ob-gyn doctors. Short training for midwives was conducted because if they could quickly read and understand the data coming out of the TeleCTG device, they could immediately respond to the results to patients. However, although TeleCTG can operate on a $1 \mathrm{G}$ network, the operation of TeleCTG requires a stable internet signal. The midwives of Puskesmas in Kupang Regency often have difficulty getting an internet signal due to geographical problems, especially during the rainy season.

Next, trialability tests the TeleCTG innovation at Puskesmas in Kupang Regency. According to the Health Office Kupang District, trials of using TeleCTG have been carried out at Puskesmas in 13 sub-districts from late 2018 to March 2019 (Swastika, 2020). Based on interviews with TeleCTG provider, Coordinator of Komunitas Bidan Sehati, and Puskesmas midwife, it was found that there was training on the use of the TeleCTG application and its benefits for midwives in dealing with at-risk pregnant patients, the flow of handling and reporting of pregnant women. The trial also checked the internet network in each region whether it could be used for TeleCTG operations. After that, the TeleCTG provider and the Komunitas Bidan Sehati evaluated Puskesmas midwives in 13 sub-districts that used TeleCTG and invited midwives from 
Table 1 Selective Coding of TeleCTG Diffusion and Innovation's Elements

Elements of Innovation Diffusion

\begin{tabular}{|c|c|}
\hline Relative Advantage & $\begin{array}{l}\text { TeleCTG examination can be done at the Puskesmas at a lower price } \\
\text { than the hospital. The Midwives do not get additional income, but there } \\
\text { is satisfaction for having a comfortable feeling, also saving both time } \\
\text { and energy. }\end{array}$ \\
\hline Compatibility & $\begin{array}{l}\text { TeleCTG is beneficial for pregnant women in at-risk trimesters. The } \\
\text { need for TeleCTG is suitable because of the complex geographical } \\
\text { conditions, infrastructure problems, and the availability of ob-gyn } \\
\text { doctors in Kupang. }\end{array}$ \\
\hline Complexity & $\begin{array}{l}\text { First, there were difficulties when changing midwives' habits from } \\
\text { manual to digital. There is a level of difficulty in installing the device } \\
\text { because it must fit in the patient's body and use a stable internet } \\
\text { network. }\end{array}$ \\
\hline Trialability & $\begin{array}{l}\text { In the previous test, the problem was regarding the understanding of } \\
\text { the tools from the midwife and the functioning of the internet network. } \\
\text { Midwives are trained to show the benefits of TeleCTG, the flow of } \\
\text { handling and reporting of pregnant mothers' health. }\end{array}$ \\
\hline Observability & $\begin{array}{l}\text { TeleCTG has a systematic and detailed data collection. The patient } \\
\text { can hear the heartbeat and fetal movements from the baby, but the } \\
\text { examination results are in the form of graphs, which cannot be } \\
\text { downloaded. }\end{array}$ \\
\hline
\end{tabular}

Source: Research primary data, 2020

Puskesmas in 11 sub-districts that had not used TeleCTG.

Lastly, observability, which means TeleCTG innovations can be observed. TeleCTG has a systematic and detailed data collection flow. Based on the interview with the TeleCTG provider, the TeleCTG data process is carried out starting from the data of the midwife, then entering the Puskesmas, then to the health office so that notifications and reports are automatically available. The health office and Puskesmas can monitor data from the initial research to the last use for cohort reports. (Waluyo, 2020). Because midwives are given training on how to read and understand the data that comes out of the TeleCTG device, the midwife can discuss the results of the TeleCTG examination with the ob-gyn doctor and convey it to the patient. According to Puskesmas midwife, feedback from ob-gyn doctors makes midwives hesitate to give action, especially in detecting heart rate and fetal movement (Sailana, 2020). However, it should be noted that, unlike ultrasound which has images of the fetus, the results of the
TeleCTG examination are only in the form of graphs. TeleCTG is intended to reduce paper usage (paperless), but the examination results cannot be downloaded in PDF or JPEG form; they only can be table 1 .

The axial coding of the midwife's participation analyzes the elements of compliance, consultation, cooperation, colearning, and collective action. At first, in the compliance element, tasks with incentives are determined with a process directed by the outsiders. Based on interviews data with the Coordinator of Komunitas Bidan Sehati and Puskesmas midwives, it is known to encourage midwives' involvement. There are incidental incentives in giving some phone credit for the internet data network and certified seminars based on online classes with benefit credits for SKP (Satuan Kredit Profesi known as Professional Credit Unit). The seminars and online classes are beneficial for promoting midwives with ASN (Aparatur Sipil Negara known as State Civil Apparatus) status. Komunitas Bidan Sehati gave this incentive to 
Table 2 Selective Coding of Midwives Participation

\begin{tabular}{ll}
\hline & \multicolumn{1}{c}{ Participation Ladder } \\
\hline Compliance & $\begin{array}{l}\text { Midwives are at the frontline of TeleCTG's usage by connecting the ob-gyn } \\
\text { doctors and patients. There are incentives, like internet network fees for } \\
\text { their phone and certified online seminars or classes for promotion. }\end{array}$ \\
They had market research and evaluation to identify problems and have \\
input from midwives. Midwives can discuss the provider through offline or \\
online training and medium like Whatsapp groups. \\
The understanding of using TeleCTG was given to the midwives. The \\
application also was modified based on the midwife's input, but not all \\
the applications were integrated. The health department also conducts \\
monitoring and evaluation. \\
Offline/ online meetings and Whatsapp groups are mediums for midwives \\
and providers to share knowledge, understand each other's desires, and \\
share their responsibilities. \\
The midwives always exchange their knowledge of tools, promote the use \\
of TeleCTG to their peers, and promote the tools inside their community.
\end{tabular}

Source: Research primary data, 2020

encourage midwives' participation based on the number of inputs for TeleCTG examinations carried out by midwives. Midwives became the frontline for showing the benefits of TeleCTG and creating promotion between ob-gyn doctors and patients.

Secondly, when the midwife's opinion is asked in the consultation element, the outsiders will analyze and decide to take action. The consultation between the TeleCTG provider and midwives was the central aspect before delivering the information to patients. From the beginning, the TeleCTG provider already researches the market or social to develop the cohort reports (reports of health problems for pregnant women and babies), which are also helped by the health office and midwives' organizations. Midwives give all the knowledge and information of using TeleCTG based on social culture and their expertise in using mobile phones. The Coordinator of Komunitas Bidan Sehati and the Puskesmas midwife admitted that the evaluation was carried out to see the obstacles and ask for some input from the midwives to improve the use of TeleCTG. After March 2019, the training continued by face-toface meeting, then after the Covid-19 outbreak, the training was done online through zoom meetings and WhatsApp groups for sharing the information of TeleCTG. The Whatsapp group, which contains all Komunitas Bidan Sehati and midwives members, has become a central platform and helps discuss complex pregnancy cases in the field and the medical actions are taken.

Thirdly in the cooperation element, midwives work together with outside parties to determine the priorities, but the outside parties settle the decision and the responsibility for directing the process. The mechanism for using the TeleCTG tool has been provided to the midwife in the initial meeting between the TeleCTG provider and the selected midwives. The provider exposes that the selected midwives that receive the TeleCTG tool had been researched and reviewed from various aspects. The midwives were also given directions and mechanisms for using the tool, from using it with a cellphone until applying it to the patient (Waluyo, 2020).

There are some notes here. Although TeleCTG has several application products like mothers, midwives, online class literacy training, Sehati Dashboard, and Sehati Consulting, not all of them are integrated into one system and receive input from the users (Sailana, 2020). Based on interviews with Puskesmas midwives, changes on the TeleCTG application are modified based on the midwife's input. In another case, The Health Office Kupang District 
Table 3 Selective Coding of Midwives Empowerment

\begin{tabular}{ll}
\hline \multicolumn{1}{c}{ Midwives Empowerment } \\
\hline Welfare & $\begin{array}{l}\text { How often midwives use TeleCTG to the patients makes them } \\
\text { receive incentives like phone credit or certified online seminars } \\
\text { and classes that are useful for promoting midwives with } \\
\text { governmental staff status. } \\
\text { The knowledge of the usage or mechanism of TeleCTG is } \\
\text { helpful because they only get the basic CTG knowledge in } \\
\text { midwifery schools. Midwives can directly handle at-risk } \\
\text { patients, monitoring, and evaluation after consulting with ob- } \\
\text { gyn doctors. } \\
\text { The Utilization of ICT in health subjects is one of the } \\
\text { performance indicators for midwives' knowledge. The ability of } \\
\text { midwives to install and practice TeleCTG affects the treatment } \\
\text { for the patients, both medically and non-medically }\end{array}$ \\
\end{tabular}

Source: Research primary data, 2020

also conducts monitoring and evaluation by looking at the conditions and needs of the Puskesmas and the local community, and share an expectation that TeleCTG can be available in all Puskesmas at 24 sub-districts. However, due to the Covid-19 condition and the availability of the budget, until the end of 2020, this desire has not been achieved considering that the price of one TeleCTG device reaches the amount of 30 million IDR (Swastika, 2020).

Fourth, the co-learning elements, known as local people and outsiders sharing knowledge, try to create new understandings and work together to form an action plan. Based on interviews with TeleCTG provider, Coordinator of Komunitas Bidan Sehati, and Puskesmas midwife, it was found that offline and online training, also Whatsapp groups were used as a facility or medium for midwives and providers to share knowledge, perfecting the tools, trying to understand each other's desires, and carrying out shared responsibilities. However, the midwife stated that the provider had a late response when the tools were damaged or had an error activity. The midwife is expecting quick responses like direct monitoring, like visiting the midwife's location to provide input and directives on using TeleCTG if they have another problem. In the beginning, the monitoring from the providers was in order, but after a few months, the frequency became irregular; it could be once or two a month.
The last one, in collective action, the midwives have their agenda in taking collective action together. It can be seen in the interview with Puskesmas midwife in Kupang:

"The Midwives always shared and exchanged their knowledge of using TeleCTG. After using the newest medical technology, all midwives are having an enthusiastic feeling and want to share their experiences with colleagues and also popularize the use of TeleCTG inside the community." (Sailana, 2020)

Based on the axial coding data on midwives' empowerment, the data were analyzed from welfare, clinical competence, and complementary competence. Starting from the welfare aspect, then the results are based on interviews with the three sources: Health Office Kupang District, the Coordinator of Komunitas Bidan Sehati, and the Puskesmas midwife; the founding shares that the provider of TeleCTG did not provide the welfare of midwives directly, but the midwives often received incentives or other benefits from Komunitas Bidan Sehati. The incentives are in the form of phone credit and certified online seminars that are useful for promotion as a midwife with governmental staff status. This incentive is given to Puskesmas midwives who actively promote and use TeleCTG to the patients. The concept for the incentive is more often the midwives examine 
Table 4 The Effect of Diffusion of Innovation on Midwives Participation

\begin{tabular}{|c|c|c|c|c|c|c|}
\hline \multicolumn{7}{|c|}{ Coefficients $^{\mathrm{a}}$} \\
\hline & \multirow[t]{2}{*}{ Model } & \multicolumn{2}{|c|}{$\begin{array}{l}\text { Unstandardized } \\
\text { Coefficients }\end{array}$} & \multicolumn{3}{|c|}{$\begin{array}{l}\text { Standardized } \\
\text { Coefficients }\end{array}$} \\
\hline & & $\mathrm{B}$ & Std. Error & Beta & $\mathrm{t}$ & Sig. \\
\hline \multirow[t]{3}{*}{1} & (Constant) & 9,342 & 5,431 & & 1,720 & ,091 \\
\hline & Total_Rev_Difusi_ & & & & & \\
\hline & Inovasi &, 625 & ,093 & 679 & 6,729 & ,000 \\
\hline
\end{tabular}

Source: Research primary data, 2020

patients with TeleCTG, the more incentives they will reach.

The aspect of clinical competence is related to the medical services from the midwife. TeleCTG is intended to increase the clinical competence of midwives at the Puskesmas because, as we know, the tools of CTG are only available at the hospitals. Based on interviews with Komunitas Bidan Sehati and Puskesmas midwife, it was found that midwifery schools only taught general CTG examinations. With the presence of TeleCTG, midwives gain can use CTG remotely. The midwives were trained based on data of the ten most common diseases for pregnant mothers, and that data was helped for the usage, monitoring, and evaluation of TeleCTG. By using TeleCTG, midwives can monitor patients with risk factors and give quick suggestions or interventions after consulting with obstetricians.

The last one is on the complementary competence aspect that concerns midwifery practices that assist in using TeleCTG. The provider state that the use of TeleCTG is a complementary competency for midwives, whereas nowadays, the use of information and communication technology (ICT) in the health sector is one of the performance indicators of midwives (Waluyo, 2020). The use of portable technology connected to mobile phones at the time of examination on patients looks sophisticated. The midwife also admits that the ability to install and practice the tools to the patients affects the process of handling patients both medically and non-medically, especially the psychological condition of the patients (Sailana, 2020).

Furthermore, from the findings of quantitative data, based on Path Analysis to test the first hypothesis, it is known that the significance value of $\mathrm{X}=0.000<0.05$ (table 1 ), thus $\mathrm{H} 1$ is accepted that there is a significant effect of $\mathrm{X}$ (innovation diffusion element) on $\mathrm{Z}$ (midwives participation).

Then in the second hypothesis, it is known that the significance value of $\mathrm{Z}=0.007<0.05$ (table 2), thus $\mathrm{H} 2$ is accepted that there is a significant effect of midwife participation (Z) on midwives empowerment (Y). Forward, the third hypothesis is known that the significance value of $\mathrm{X}=0.087>0.05$ (table 2 ), thus H3, is rejected, which means there is no significant influence of the innovation diffusion elements $(\mathrm{X})$ on the empowerment of midwives $(\mathrm{Y})$.

Finally, the fourth hypothesis with the criteria the value of $Z$ count $>1.96$. To find out $\mathrm{Z}$ count, then the following formula is used:

$$
\begin{aligned}
& \mathrm{Z} \text { count }= \\
& \sqrt{\mathrm{p} 1 . \mathrm{p} 2} 2^{2} \mathrm{Sp} 1^{2}+\mathrm{p} 1^{2} \mathrm{Sp} 2^{2}-\mathrm{Sp} 1^{2} \mathrm{Sp} 2^{2}
\end{aligned}
$$

It is known that the beta of innovation diffusion elements $(\mathrm{p} 1)=0.679$ and $\mathrm{t}$ count $(\mathrm{t} 1)$ $=6.729$ (table 1), while the beta of midwives participation $(\mathrm{p} 2)=0.418$ and $\mathrm{t}$ count $(\mathrm{t} 2)=$ 2.826 (table 2).

$$
\begin{aligned}
& \mathrm{Sp} 1=\frac{\mathrm{p} 1}{\mathrm{t} 1}=\frac{0,679}{6,729}=0,1009 \\
& \mathrm{Sp} 2=\frac{\mathrm{p} 2}{\mathrm{t} 2}=\frac{0,418}{2,826}=0,1479
\end{aligned}
$$

Therefore:

$\mathrm{Z}$ count $=$

$\frac{0,679 \times 0,418}{(0,418)^{2} \times(0,1009)^{2}+(0,679)^{2} \times(0,1479)^{2}-(0,1009)^{2} \times(0,1479)^{2}}$
$=2,62$


Table 5 The Effect of Innovation Diffusion Elements and Midwives Participation on Midwives Empowerment

\begin{tabular}{|c|c|c|c|c|c|c|}
\hline \multicolumn{7}{|c|}{ Coefficients $^{\mathrm{a}}$} \\
\hline & \multirow[t]{2}{*}{ Model } & \multicolumn{2}{|c|}{$\begin{array}{c}\text { Unstandardized } \\
\text { Coefficients }\end{array}$} & \multicolumn{3}{|c|}{$\begin{array}{l}\text { Standardized } \\
\text { Coefficients }\end{array}$} \\
\hline & & B & Std. Error & Beta & $\mathrm{t}$ & Sig. \\
\hline \multirow[t]{3}{*}{1} & (Constant) & 7,471 & 3,394 & & 2,201 & ,032 \\
\hline & Total_Partisipasi & ,236 &, 084 & ,418 & 2,826 & ,007 \\
\hline & Total_Rev_Difusi_Inovasi & 134 & 077 & 258 & 1,744 & 087 \\
\hline
\end{tabular}

a. Dependent Variable: Total_Pemberdayaan

Source: Research primary data, 2020

With $\mathrm{Z}$ count $2.62>1.96$, then $\mathrm{H} 4$ is accepted, there is an indirect effect of the innovation diffusion elements $(\mathrm{X})$ on the midwives' empowerment $(\mathrm{Y})$ that is mediated by the midwives' participation $(\mathrm{Z})$.

Based on PathAnalysis, the conclusionis that the innovation diffusion elements of TeleCTG encourage the participation of midwives. This is related to the need of Puskesmas midwives for the presence of TeleCTG, which assists them in handling risk patients like pregnant women in Kupang. However, the diffusion of innovation in the use of TeleCTG does not directly affect the empowerment of midwives at the Puskesmas in Kupang. The participation of midwives influences the empowerment of midwives. The diffusion of innovation only has an indirect effect on the empowerment of midwives that is mediated by the participation of midwives. Therefore, the participation of midwives can be the vital aspect or key in the process of innovation diffusion to increase the empowerment of Puskesmas midwives in Kupang.

The qualitative and quantitative data results can be interpreted sequentially from the elements of innovation diffusion, midwives' participation, and midwives' empowerment. Based on the elements of innovation diffusion, the persuasion process has been seen in the element of relative advantage. This element showed results that the presence of TeleCTG brings local communities closer to proper health facilities, thus affecting the maternal and infant mortality rate. Patients at health centers like Puskesmas can be examined using a cardiotocography facility, which so far can only be enjoyed by patients in hospitals - using TeleCTG as examinations tools at Puskesmas shared economic benefit to patients because of the free treatment and the distance problem to the hospital. For midwives, even though they do not get additional income, the presence of TeleCTG reduces the worry of dealing with risk patients. Midwives also gain social prestige because of the positive response from patients to health services that use advanced technology. Moreover, in the compatibility elements, the problem of geographical conditions, infrastructure, and the absence of ob-gyn doctors in Kupang make TeleCTG necessary tools for maternal patients. TeleCTG is also practical to carry and can be used in areas with only one $(1 \mathrm{G})$ internet signal, making this tool suitable for Puskesmas in remote areas.

In terms of complexity, this research's findings show a level of difficulty, including the midwife's skills in installing the device into the patient's body and reading the data from the TeleCTG's results examination. However, that condition can be solved with the training that given by the provider to the midwives. Somehow, the nature problem like the rainy season can influence the instability of the internet signal in Kupang, and that condition can create a new challenge for the improvement of the tool in the future. However, in terms of trialability, some trials have been conducted in thirteen Puskesmas with prospective adopters to collect data that included internet signal network, the training process for at least two midwives from each Puskesmas, and an evaluation process for each other. It means that the trial has been carried out based on the environmental conditions of 
the prospective adopters.

Furthermore, inside the observability element, the innovation from TeleCTG can be observed from the shifting usage of manual to digital technology to create a cohort report. Midwives and obstetricians can also read the examination reports to create rapid action on at-risk patients. However, some suggestions on the reports are in the form of a graphic and only can be seen by screenshotting the image, not downloading it, that need to be improved to simplify the utility.

From the five elements of innovation diffusion, it can be seen that the elements of relative advantage, compatibility, and observability give many advantages to the local communities and support their quality of health services. The Trialability and Complexity elements have also been improved, except for the signal and internet network's instability problem.

Based on the participation of midwives, the compliance element shows the presence of the midwives as the front line of TeleCTG as a new technique and medicine tools and they will have an incentive to measure the activeness of using TeleCTG to the patients, this means there is an agenda that directed by outsiders for the midwives. From the consultation element, the market research and the evaluation are carried out by asking for some input from midwives. Thus, this element is qualified because there is a discussion and input from the locals, in this case, are the midwives, before the provider, as the outsider decided to take action.

Inside the cooperation element, the local or the midwives work together with outsiders or the providers to determine some priorities, like the responsibility for directing the process, that the decision always come back to the providers. Midwives were asked for their input to improve the tool, but it should be noted that not all applications in TeleCTG are integrated into one system. It also shows that the health office monitors and has evaluations that suggest the need for TeleCTG for Puskesmas on 24 subdistricts in Kupang.

The other element, like co-learning, shows that offline and online training, also Whatsapp groups are used as a medium for midwives as local people to share knowledge, understand each other's expectations, and share responsibilities with the providers. On the other hand, the midwives admit that the provider sometimes is late to respond if there is a case of equipment failure that also expects close monitoring. Lastly, in collective action, midwives as local people have their agenda, which includes exchanging knowledge, promoting the new tools to their peers, and promoting the use of TeleCTG in their community.

From the explanation above, it can be seen that five elements of participation are already as expected, doing well and creating some new findings, starting from the provider's agenda and direction as outsiders facilitated by Komunitas Bidan Sehati. The activity of monitoring and evaluation from the health office and midwives' involvement in sharing the new medicine tools. The results of the Path Analysis showed that there was a significant effect of the innovation diffusion on midwives' participation. The Midwives' participation is related to the elements of compliance, consultation, cooperation, and co-learning, which is aspirational to midwives that connect to the collective action element, which shows midwives actively share their knowledge and promote TeleCTG to their communities. However, the participation of midwives will not reach higher if the availability of TeleCTG is lacking or not needed by Puskesmas midwives in Kupang.

Health technology based on mobile (m-Health) has developed to improve maternal and child health in the last decade. This technology helps call emergency transportation, long-distance consultations, or having a community education program based on short message service (SMS). This new technology in the health area is helpful in remote and lowresource areas worldwide (Speciale \& Freytsis, 2013).

From the findings, we can learn that TeleCTG is one step ahead of other tools because it provides remote examination services and diagnosis results for at-risk maternal patients from remote areas, leading to fast handling services. Patients do not have to go to hospitals in urban areas to diagnose their health conditions. This statement is in line with a study that shared the increase pf price on health services is related to the difficulty of access and the low quality of health services, which impact the high mortality rate (Fai et al., 2017).The other point of view is coming from 
the empowering of midwives. Empowerment is a significant concept for midwives because it is commonly used in health care and professions related to clinical practice. Midwives are considered close with health care consumers and have a significant impact on many individuals and families (Hermansson \& Mårtensson, 2011: 816). The presence of TeleCTG makes midwives have some advantages on the welfare side, clinical competence, and complementary competence.

Nevertheless, the problem is that empowerment needs to be understood in the socio-cultural, economic, and political context of individuals, whose have an internal belief to open themselves up to the experience of empowerment (Nieuwenhuijze \& LeahyWarren, 2019). Midwives' participation in using TeleCTG makes them better to treat pregnant women in their communities with different socioeconomic landscapes or areas with transportation infrastructure problems and limited local health facilities. By using TeleCTG to the patients, midwives will receive incentives for their services. In addition, midwives will also have new knowledge and experience by consulting with ob-gyn doctors and have expertise in health ICTs that affect the process of treating patients both medically and non-medically.

The Path Analysis findings show that the diffusion of innovations from using TeleCTG does not directly affect the empowerment of midwives at Puskesmas in Kupang. The participation of midwives directly influences the Empowerment of midwives. The innovation diffusion of TeleCTG only has an indirect effect on the empowerment of midwives that is mediated by the participation of midwives. The participation of midwives is key to the process of diffusion of innovation to increase the empowerment of local midwives at Puskesmas in Kupang.

Different factors influence the diffusion and the adoption of new technologies, such as the presence and usage of innovation transformations for daily activities that are connected to validating the innovations in their social systems (Gabriel \& Silva, 2017: 22). In this study, the participation and empowerment of midwives became two inseparable factors for the process of innovation diffusion of TeleCTG as a new tool. Although there are some technical problems as a new tool, the innovation diffusion of TeleCTG has proven to affect the participation of Puskesmas midwives because of the midwives' need for the tool in handling at-risk pregnant women patients. That condition is also related to social conditions, infrastructure, facilities, and availability of medical personnel in Kupang. The high participation of midwives for using TeleCTG encourages the empowerment of midwives, which has an impact on improving the quality of health services for pregnant women in remote areas.

\section{CONCLUSION}

As the front line of health services for pregnant women, Puskesmas in Kupang already face challenges in terms of geography, infrastructure, local socioeconomic conditions, and the uneven quality of health services in the surrounding area. TeleCTG as new technology is seen as a way out because midwives at health centers in remote areas like Kupang have the opportunity to consult with ob-gyn doctors remotely, which leads to action against pregnant women being at risk, which directs to reduce maternal mortality and infant mortality.

The diffusion of innovation in the use of TeleCTG influences the participation of midwives at the Puskesmas in Kupang. However, the diffusion of innovation has an indirect effect on the empowerment of midwives, which is mediated by the participation of midwives. The empowerment of midwives is directly influenced by the participation of midwives, which means the participation of midwives is the key in the diffusion of innovations to increase the empowerment of local midwives.

Midwives need the presence of TeleCTG according to local conditions. However, the provider needs to improve the technologies on tools, especially the non-integration of all applications on the TeleCTG tool and the inspection results that cannot be downloaded. The providers also need to monitor the tools regularly and respond to input or complaints from midwives as the users. TeleCTG will be a more user-friendly medical tool for midwives in treating patients with these improvements. In addition, the TeleCTG examination also needs to be fought to be included in the BJPS component in the Indonesian health system, which leads to 
additional income for the midwives.

This research shows that the concept of innovation diffusion needs to be linked to participation so that the process does not run linearly and top-down. Furthermore, subjects who are the targets of this innovation diffusion must be empowered to create a better process that also can be sustainable. Therefore, participation and empowerment become an inseparable part of innovation diffusion. For further research, there would be great if some research showed the use of TeleCTG by other midwives in other districts with different geographical conditions, infrastructure, socioeconomic conditions, and health facilities. The aim is to compare and see the link between participation and empowerment in the innovation diffusion process of TeleCTG as a new tool in health technology.

\section{REFERENCES}

Badan Pusat Statistik Kabupaten Kupang. (2021). Kabupaten Kupang dalam angka 2021. Kabupaten Kupang: Badan Pusat Statistik Kabupaten Kupang.

Badan Pusat Statistik RI. (2020). Profil kesehatan ibu dan anak 2020. Jakarta: Badan Pusat Statistik RI.

Bowen, P., Rose, R., \& Pilkington, A. (2017). Mixed methods-theory and practice. Sequential, explanatory approach. International Journal of Quantitative and Qualitative Research Methods, 5(2), 1027. Retrieved from www.eajournals.org

Creswell, J. W. (2017). Research design: pendekatan metode kualitatif, kuantitatif, dan campuran. Yogyakarta: Pustaka Pelajar.

Dearing, J. W., \& Cox, J. G. (2018). Diffusion of innovations theory, principles, and practice. Health Affairs, 37(2), 183-190. https://doi. org/10.1377/hlthaff.2017.1104

Fai, I.F., Pandie, D.B.W., \& Ludji, I. D. R. (2017). Manajemen sumber daya terhadap mutu pelayanan Neonatus di Puskesmas PONED Oesao Kupang. Unnes Journal of Public Health, 6(2), 84-91. https://doi. org/10.15294/ujph.v6i2.10746

Gabriel, M. L. D. S. \&, \& Silva, D. D. (2017). Diffusion and adoption of technology amongst engineering and business management students. International Journal of Innovation, 5(1), 20-31. https:// doi.org/10.5585/iji.v5i1.80

Grace, J \& Grace, P. (2017). 360 o participation: participation youth handbook. Erasmus + Programme.

Hermansson, E., \& Mårtensson, L. (2011). Empowerment in the midwifery context-a concept analysis. Midwifery, 27(6), 811-816. https://doi.org/10.1016/j. midw.2010.08.005

Huiberts, E. (2016). Building bridges, filling gaps: toward an integrative interdisciplinary and mixed-methods approach for future audience research concerning the mediation of distant suffering. International Journal of Communication, 10, 4324-4344.

Kanji, N \& Greenwood, L. (2001). Participatory approaches to research and development in IIED : learning from experience. London: IIED.

Katona, Z., Zubcsek, P.P., \& Sarvary, M. (2011). Network effects and personal influences: the diffusion of an online social network. Journal of Marketing Research, 48(3), 425-443. https://doi.org/https://doi. org/10.1509/jmkr.48.3.425

Leech, N.L., Onwuegbuzie, A.J., \& Combs, J. P. (2011). Writing publishable mixed research articles: guidelines for emerging scholars in the health sciences and beyond. International Journal of Multiple Research Approaches, 5(1), 7-24. https://doi.org/ https://doi.org/10.5172/mra.2011.5.1.7

Nieuwenhuijze, M. \&, \& Leahy-Warren, P. (2019). Women's empowerment in pregnancy and childbirth: A concept analysis. Midwifery, 78, 1-7. https://doi. org/10.1016/j.midw.2019.07.015

Parston, G., McQueen, J., Patel, H., Keown, O.P., Fontana, G., Kuwari, H.A., \& Darzi, A. (2015). The science and art of delivery: accelerating the diffusion of health care innovation. Health Affairs, 34(12), 2160-2166. https://doi. org/10.4324/9781315699042

Putri, N. E., Hakim, N., \& Yamin, M. (2016) Ecologicall Footprint and Biocapacity Analysis for Flooding Prevention in South Sumatera. Jurnal Mimbar, 32(1), 58-64.

Rogers, E. M. (2003). Diffusion of innovations (Fifth Ed.). New York: New York: Free 
Press.

Sailana, M. A. (2020). Personal Interview.

Sariyati, Wahyati, E., \& Kuntjoro, C. T. (2012). Peran Bidan dalam Pelaksanaan Permenkes No. 631/MENKES/PER/ III/2011 sebagaimana Telah Diubah Dengan Permenkes Nomor 2562/ MENKES/Per/XII/2011 Tentang Petunjuk Teknis Jaminan Persalinan (Studi Kasus Pelayanan Kebidanan di RSUD Dr. $H$. Soewondo Kendal). Unika Soegijapranata Semarang. https://doi.org/https://doi. org/10.24167/shk.v2i2.824
Shinta, E. (2020). Personal Interview.

Speciale, A. M., \& Freytsis, M. (2013). mHealth for midwives: a call to action. Journal of Midwifery and Women's Health, 58(1), 76-82. $\quad$ https://doi.org/10.1111/j.15422011.2012.00243.x

Swastika, T. (2020). Personal Interview.

Tajmiati, A., Astuti, K.E.W., \& Suryani, E. (2016). Konsep kebidanan dan etikolegal dalam praktik kebidanan. Jakarta: Pusdik SDM Kesehatan.

Waluyo, A. (2020). Personal Interview. 